\title{
Innovation in the south-eastern Alps: maize as a crop in Carinthia until the middle of nineteenth century
}

\author{
Werner Drobesch \\ University of Klagenfurt, History Institute
}

\section{Introduction}

At the beginning of the twenty-first century, maize (Zea Mays L.) is of great importance in agricultural production in the south-eastern Alpine countries, and thus also in Carinthia, as a crop and food for humans and animals. There are mountains of maize. Of all the crops, it was the one that changed the agricultural structure and the landscape sustainably over the past two centuries. In 2013, silage maize and grain maize were grown on 24,943 hectares or $62.5 \%$ of Carinthia's arable land (Tschischej 2013, 6). This resulted in a harvest quantity of approximately 125,000 tons and an average harvest of 5 tons per hectare. Even though cultivable land is now declining, maize pushed the other grain types into the background. At the beginning of the twenty-first century, it is the most important arable plant within the grain cultivation system in Carinthia. Given its importance within the agricultural production process, it is surprising that the development of maize cultivation has only been marginally touched on in agricultural history research. Little attention is paid to it in the descriptions of the agricultural development and history of plant cultivation. The number of relevant publications is extremely marginal (Dinklage 1966; Erker 2003; Wadl 1987; Zeloth 2013). This study is an attempt to fill this research gap. 


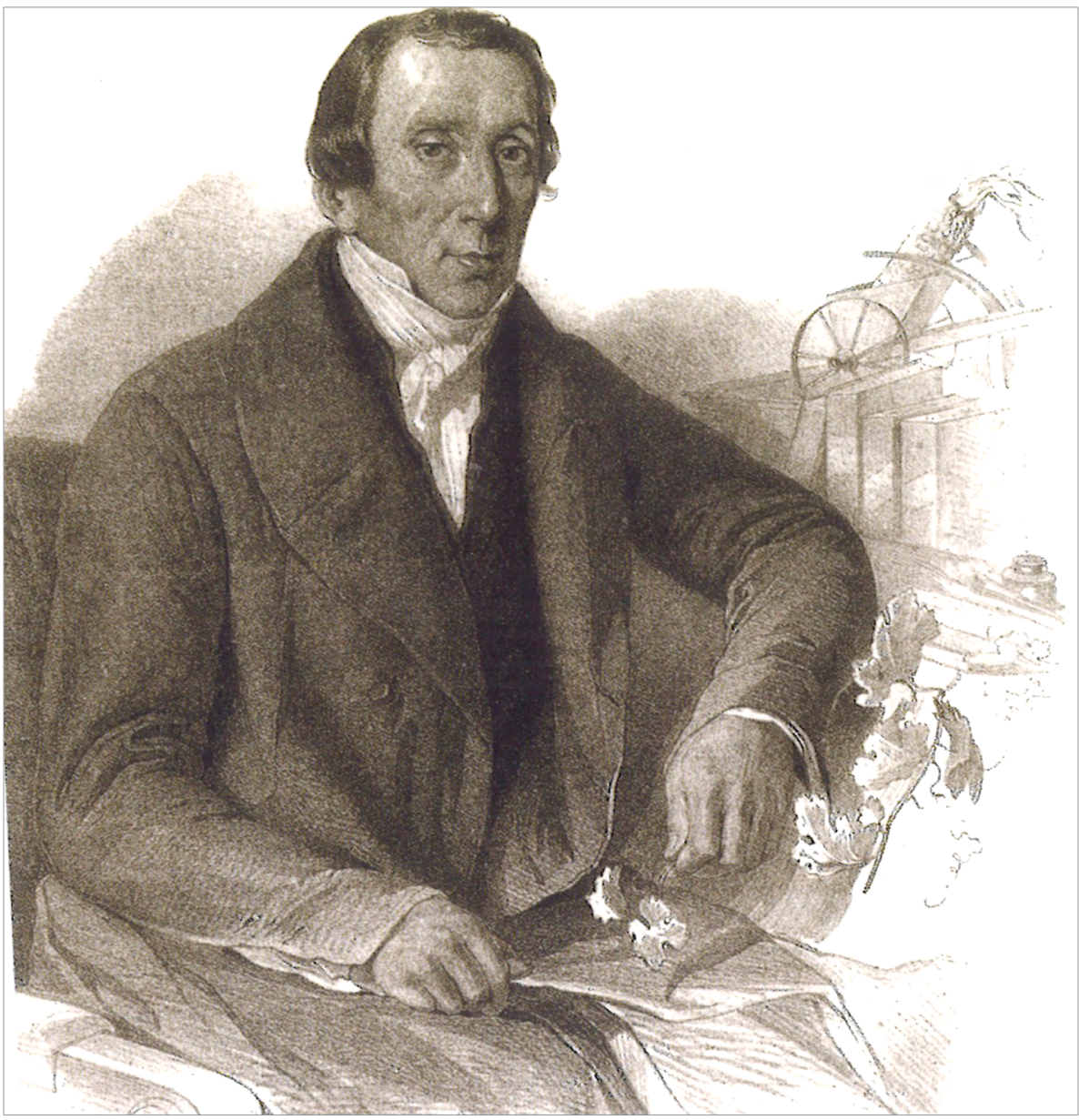

Figure I. Johann Burger

Source: Wadl 2009.

Observations and reflections by maize expert Johann Burger

Its ascent to the most important arable plant was slow. In other territories of the Alpine region, such as Tyrol or Vorarlberg, it prevailed earlier. For a long time, the thesis prevailed that it only became part of the crop rotation system in the second half of the eighteenth century, coming from Italy and Hungary (Dinklage 1966, 175). This assumption was based on Johann Burger (see Dinklage 1970), agricultural expert and professor of agriculture at the Klagenfurt Lyzeum, who published a comprehensive treatise on maize in 1809 (Burger 1809). For decades, his “maize monograph" was a standard work 


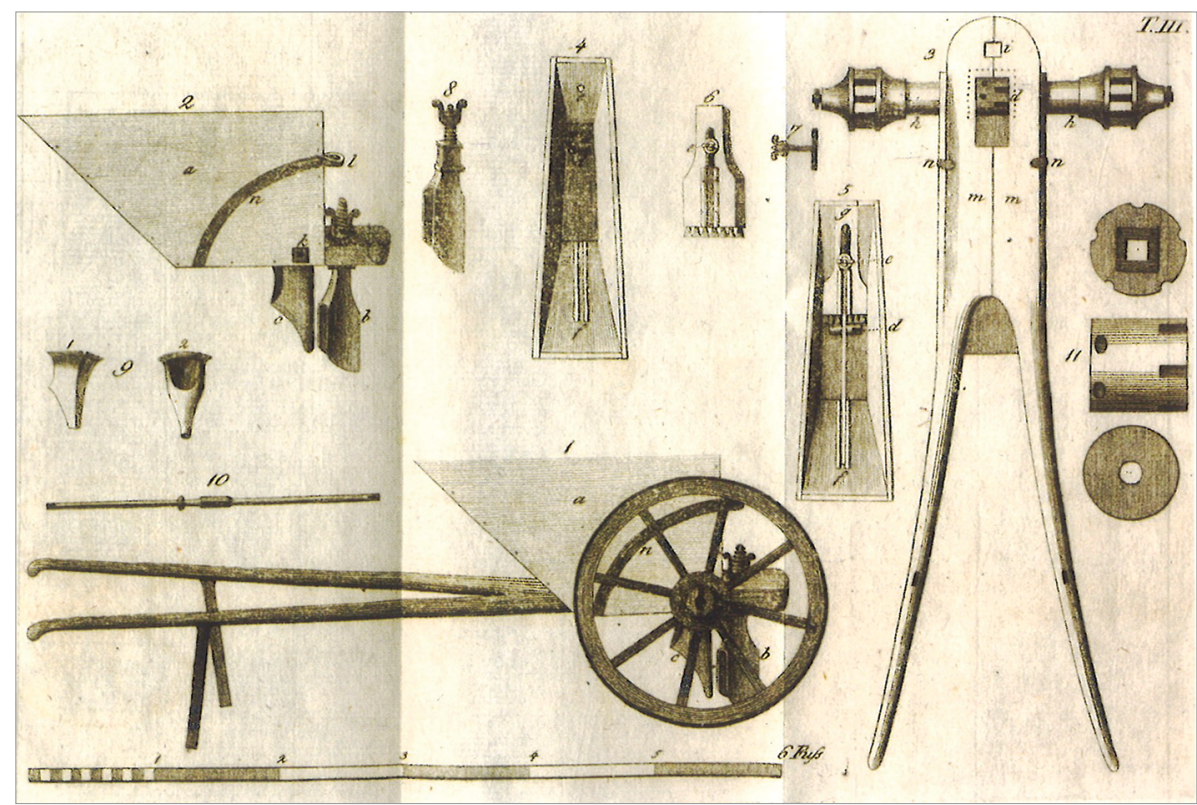

Figure 2. Maize seeder

Source: Burger 1809.

in agricultural science research. Even today, it is one of the "classics" of specialist literature on maize cultivation. The Carinthian agricultural scientist euphorically reports about the spread of maize at the turn of the nineteenth century: "Since maize cultivation has become more widespread in Carinthia, agriculture has started to ascend to a higher level. [...] Now they produce the most abundant maize in fields that otherwise bore meagre amounts of rye, lentils and buckwheat. You have the richest harvests, [...] and you also get [...] more than half of the grain" (Burger 1809, 77f.), unlike before. What started on a small scale, spread especially in the "wild and fertile" Lavant Valley (Lavanttal), but also "in the rough heights of the Gail Valley and Drava Valley (Gailtal, Drautal), at the foot and sometimes even in the gorges of the Noric Alps" (Burger 1809, 79). Burger looked to the future expectantly: "It is impossible to determine how many yokes in Carinthia are being planted with this crop annually; I hope that maize cultivation will increase as it had over the past twenty years. If so, in fifty years the fifth of all the fields in the plains and valleys of this country will be sown with maize." (Burger 1809, 79).

Carinthia was not an isolated case in this regard. At that time, maize had already become homegrown in many areas of Central Europe: 
"Moravia produces quite a lot of maize in Brno and in the Hradischer district, bordering Hungary. It is also often planted in Württemberg [...] and its culture grows there every year. There is also extensive maize cultivation in Tyrol, Switzerland and Alsace, where they cultivate large fields with it." (Burger 1809, 79). On the other hand, in many territories of the Holy Roman Empire, namely in "Austria, Bohemia, Moravia, Silesia, Franconia, the Lower Rhine area, Saxony, [and] the Marches", which had an unfavourable climate for growing maize, no maize was grown at all, or it was of such "poor quality that it could not be grown as a crop" (Burger 1809, 83). The crop yields were correspondingly low. In Austria and Moravia there were no more than 12 hectolitres per 0.01 hectares. Carinthia was slightly better in this regard. There, the yield averaged 24 to 30 hectolitres per 0.01 hectares. That was a good amount because, according to Burger, 42 hectolitres per 0.01 hectares were "with our current knowledge and tools" the greatest possible yield (Burger 1809, 291).

\section{Every beginning is hard}

At this point in time, maize cultivation was no longer a revolution for Carinthian agriculture. It had spread too much, even if it was far from widespread. The beginnings go back to the middle of the sixteenth century. Its first appearance can be documented as early as 1559 (Wadl 1987, 240). A business letter between a landlord and his administrator is the oldest archival source in the area of present-day Austria in which maize is mentioned. It mentions that the economic administrator of the Gurk cathedral, Wilhelm Wernher von Wernhof - the "Wernhof" is a noble estate in central Carinthia near Althofen -, sent his brother-in-law Hans Raidhaupt an unspecified amount of maize with the request to forward it to the earl of Hardegg: "I would like to thank Wernher for the türkischen Weizen [Turkish wheat]" (Wadl 1987, 240). This mention proves that the maize which had come to Carinthia shortly before that time - here referred to as "Turkish wheat" - was occasionally cultivated in the Krappfeld region. However, it is not clear where it came from and whether Wilhelm von Wernhof harvested it at Krappfeld or received it from a third party. In view of the detailed mention and the special thanks for the gift, it may be assumed that maize was still a rarity in Carinthia in 1559. Wilhelm Wernher probably came into possession of the seeds due to the far-reaching relationships of the Gurk bishop. Bishop Antonius von Salamanca-Hoyos (15261551) had family ties with Spain, which would make a direct import from 
there possible (Wadl 1987, 241). This proof of the occurrence of maize remained an isolated case for a long time.

It is not possible to determine from the sources available whether maize was planted in the following decades and in the seventeenth century. Thus, it was limited to the status of a botanical rarity until the early eighteenth century. Around 1720, it appeared in the crop rotation of the Upper Drau Valley. In 1717, we come across it in the Spittal an der Drau area. In a bequest inventory 162.9 litres of Türggen are specified. Not far away, in the area around Greifenburg, it was also documented. In a dispute between the dominion of Greifenburg and its subjects, the latter claimed that maize was free of tithes, because it was a recently introduced crop. But it was not so. After studying the old inventories, it became apparent that the first very insignificant cultivation of maize occurred there in 1720 (ZeneggScharffenstein 1930, 55). However, maize was barely noticed until 1740 and was still in its infancy in the following years. The yields were very low due to the unorganized cultivation and its planting was not attractive due to the low market prices. The situation changed in the mid-176os, when at the instigation of the Radlach Pastor Franz Xaver Presenn it spread across the entire valley (Zenegg-Scharffenstein 1930, 55). From the Upper Drau Valley, it spread down the Drau River in the second half of the eighteenth century towards Central and Lower Carinthia (Wadl 1987, 243).

Lesach Valley (Lesachtal) and Gail Valley can be mentioned as another cultivation area during the same period. However, Johann Burger's statement claims that the "Turkish wheat" was naturalized there, mediated through Italy, and spread from there to the rest of Carinthia. In the first half of the eighteenth century, it was first encountered in the Lesacht Valley, replacing buckwheat. However, due to the climatic conditions, it could only be grown in the eastern part of the valley. At the same time, it replaced buckwheat as a staple. The cultivable land remained small (Neumann 1997, 205). On the other hand, there is no evidence of maize cultivation in the estate inventories of the farms in the neighbouring Gail Valley for the years before 1740. The first news of maize came from the dominion of Aichelburg in 1742 and 1743. In the following years, it established itself as a new field crop alongside the traditional cereals. The trail can be followed further. Almost at the same time, maize cultivation can also be demonstrated for the area around Villach, namely for the owners of the dominions of Landskron and Velden. The first mention refers to St Magdalen (1739), and the others to Rajach (1742), Föderlach (1755) and Kleinvassach (1756). Most 
of the evidence comes from small peasants, who were able to improve their self-sufficiency with the more profitable maize (Wadl 2019, 243).

In this context, a linguistic specificity is of interest. The term türkischer Weizen (Turkish wheat) is a synonym for maize that was used in German until the nineteenth century. Afterwards, it was shortened to Türken. In this form, the term was adopted in other compounds such as Türkensterz, Türkenmus or Türkentschurtschen. There are two interpretations associated with the word Türken: one claims that it came to Carinthia via the Ottomans (= Türken). The other points out that the tuft of styles on the maize cob suggests associations with the beard of a Turkish man. Variations of the word Türken can also be found in the Slovenian dialects of Carinthia. In short: The development of maize cultivation is reflected in these two different names, which have a geographically clearly delineated distribution area: In the Jauntal and Lower Rosental valleys, it was or is referred to in Slovenian as turšca or turščica, while in the Upper Rosental Valley the term sirk dominates. Wadl assumes that both Slovenian terms derive from German, that is turščica from Türken and sirk from türkische Hirse (Turkish millet), since Sürch was used also in the German language island of Lusern in Trentino and was derived from the Italian sorgo turco (Wadl 1987, 250); on the contrary, Slovenian authors do not necessarily believe that these words came from German. ${ }^{\text {' }}$

From the middle of the eighteenth century onward, maize began to spread rapidly. It was not only reform politicians and agricultural scientists from the late eighteenth and early nineteenth centuries who sought to improve the self-sufficiency of the population by introducing new crops, so did the Carinthian agricultural society Agrarcultur-Societät. In some places, their initiatives were heard. By 1780 , maize was probably more widespread. The inventories of a farm in Vorderberg for the years 1727, 1743 and 1786 documented the growth of maize cultivation very well. While the türkischen Weizen (Turkish wheat) was not mentioned in 1727, there were approximately 285 litres or 215 kilograms of it in 1743, and approximately 900 litres or 675 kilograms in 1786. That was not yet a great amount. It can also be found in the neighbouring dominion of Wasserleonburg. Already in 1719, polenta - a porridge made from maize grits - was on the menu of the subjects of the dominion as a main course for lunch or dinner. This is the earliest example of extensive maize consumption (Wadl 1987, 166). Maize continued to be grown in the following years. In 1750, maize cultivation in 
Wasserleonburg had already reached such an intensity that the dominion felt compelled to secure its income by regulating the tithe with regard to the new crop. From about 20.5 litres of seed, peasants had to deliver 15 kreutzers as a tenth. In 1750, a total of 1,200 litres or approximately 860 kilograms were planted in Saak, Nötsch and Förk, which corresponded to a cultivated area of approximately 15 hectares. Maize was also an important crop for miners (Zeloth 2004, 156). This evidence corroborates the assumption that the maize coming from northern Italy first spread to Upper Carinthia and then to Central Carinthia. Since the middle of the eighteenth century, there was a more intensive spread along the Drava River towards Lower Carinthia. This is how the maize got into the Lavant Valley (Sandgruber 1982, 46). The Carinthian Agrarcultur-Societät, founded in 1764, played a significant role in its dissemination. In an effort to introduce new crops, the Societät also propagated maize cultivation - with success (Bäck 2005, 45). The peasants, especially on estates like Arnoldstein, focused more and more on the cultivation of "Turkish wheat". This was how they compensated "for the grain shortage [...] to the extent that many peasants who previously had to buy grain could now sell maize themselves" (Roth 1970, 351). The decisive factor for getting to know each other and subsequently for the spread of the new arable crop was probably that the so-called Italienstraße led through these areas (Roth 1970, 351). Around 1780, maize was encountered sporadically in the Upper Lavant Valley, for instance on mountain farms near Frantschach, and in Central Carinthia near Krumpendorf or Hohenfeld (Dinklage 1966, 175). In 1794, the Agrarcultur-Societät started a new attempt to make maize an integral part of crop rotation in Carinthia. For this purpose, seeds from Venetia were permitted. In the end, maize did not succeed. A completely different development from that in Upper and Central Carinthia occurred in south-eastern Carinthia (Lower Carinthia). Until the early nineteenth century, there was no evidence of maize cultivation there.

In the following two decades, a selective spread began. The same applies to the south-eastern Carinthia area. For example, it is not mentioned in the inventories of the largest dominion Bleiburg for the years before 1800 (Lackner 2014, 245). The reasons lie, on the one hand, in agricultural backwardness, and in the dominance of buckwheat, on the other. The inventory Inventarium des Erbherzogtums Kärnten (1780), written by Vinzenz von Rosenberg, provides a description of the status quo regarding maize. It reads: "In Upper Carinthia, the food of the peasant mostly consists of 
Turkish wheat, whereas in Central and Lower Carinthia buckwheat, grain and wheat are paid as a tithe." (AT-KLA, 118-Rosenberg, Table 3). The period of the Napoleonic Wars initially delayed its further expansion. But the longer the armed conflict lasted, the greater the efforts made by politicians to improve self-sufficiency in agriculture due to the food shortage with the introduction of new, more productive crops. This also included the potato, which the people were still very reluctant to consume, and above all the expansion of maize cultivation. Johann Burger was the biggest advocate of the latter, because he saw maize as a more productive grain than the conventional ones. In 1804, he began extensive experiments with maize, which he was the first to sow in rows with the seeder. As a result of his multi-year trials, a comprehensive study (Vollständige Abhandlung über die Naturgeschichte, Cultur und Benützung des Mais oder türkischen Weitzens) emerged in 1809. Burger, who dealt with maize until the end of his life, believed that the "common peasant", even "if he is still as stupid and lagging far behind every other culture, as he is in Carinthia [...], would make a difficult decision to introduce new field systems and crop rotation; but it is wonderful how quickly the maize spreads. It is impossible to determine how many yokes are being planted with maize each year" (Burger 1809, 77). In the year of his death, 1842, a follow-up essay appeared in the Carinthia newspaper (Burger 1842, 4-6). In it, the Carinthian agricultural economist is surprised to find that the maize spread "along the entire length of the Drava River to Lienz". It was also grown in the Möll Valley (Mölltal). In Winklern, several peasants had started to cultivate it between 1780 and 1790. Between St. Veit an der Glan and Klagenfurt you could see the "most beautiful maize fields, the range of which increases every year" (Burger 1842, 6). However, it was not so easy to make maize known to the rural population as a crop and food. Burger describes in detail the problems associated with the introduction of maize at the beginning of the nineteenth century: "There was a time when aversion to maize was particularly strong in [...] Carinthia [...] But they were able to overcome this prejudice." (Burger 1809, 73).

\section{Maize becomes an integral part of agriculture and food}

When Burger died, maize was already firmly anchored in people's minds as food. External constraints, the food shortage in the era of the Napoleonic Wars, and the poor harvests in the "year without summer" after the eruption of Mount Tambora (Indonesia, 1815) forced peasants to grow these new high-yielding crops after the failure in the buckwheat harvest. A virtue 
was made out of necessity. Now the peasants were increasingly relying on maize. Joseph Hain noted in his Handbuch der Statistik that in addition to the two main crops, oats and rye, maize was grown as a crop in the flatter southern regions of the country (Hain 1853, 26). The scepticism was gone. The first signs of its increasing acceptance can be found in 1803 when it was first offered on the Klagenfurt weekly market. However, it did not begin its triumphal march as a market crop and foodstuff (Türkensterz, polenta) until the 1830s, when it also gained acceptance as a food outside the cultivation centres, thanks to the support of the Agrarcultur-Societät. In 1830, its president considered the expansion and promotion of maize cultivation a priority objective. He noted that maize cultivation had made great strides in some areas of Carinthia, but it "has not yet been introduced in others areas where it would also thrive" (Mayr 1831, 26f.). In that year the acreage was about 2,700 hectares ( $=2$ percent of the arable land) (Sandgruber $1982,46)$. However, the cultivation was mainly for local use. A comparatively tiny area of $0.1-0.2$ hectares was enough to achieve self-sufficiency. The Franciscean Cadastre provides comprehensive information about its distribution during the pre-March period. Of the 809 cadastral communities in Carinthia, 279 (34.5 percent) reported growing maize. By 1830, the maize acreage already comprised 2,742 hectares, or 2.1 percent of the total arable land. The Klagenfurt district accounted for 46.6 percent (see Map 1). For all of Carinthia, the harvest yield was 4,484 tons, of which 2,144 tons were in the Klagenfurt district and 2,432 tons in the Villach district. Across the country, 1,636 kilograms were harvested per hectare. That was more than twice as much as for wheat, oats, rye or barley (Table 1). In the Klagenfurt district, the yields were 1,676 kilograms per hectare; in the Villach district, 1,601 kilograms per hectare. The increase in yield was accompanied by higher per capita consumption. In the Klagenfurt district, consumption equalled 14 kilograms per capita; in the Villacher district, 22 kilograms per capita, which was significantly above the national average (17.3 kilograms per capita) (Table 2). Maize had become an important nutritional alternative (Drobesch 2003, 95). In comparison, the consumption of potatoes at 5.4 kilograms per person per year was still low. Wherever maize was planted, the level of supply of the population was given (compare Map 2 with Map 1). Regardless of the increasing yields, the cultivation was classified as not very intense. But in the rural households the so-called Türkenhauen (Turkish skins) and Türkenkrallen (Turkish claws) devices were increasingly to be found, which were needed for the maize harvest. Türkenfedern (Turkish 


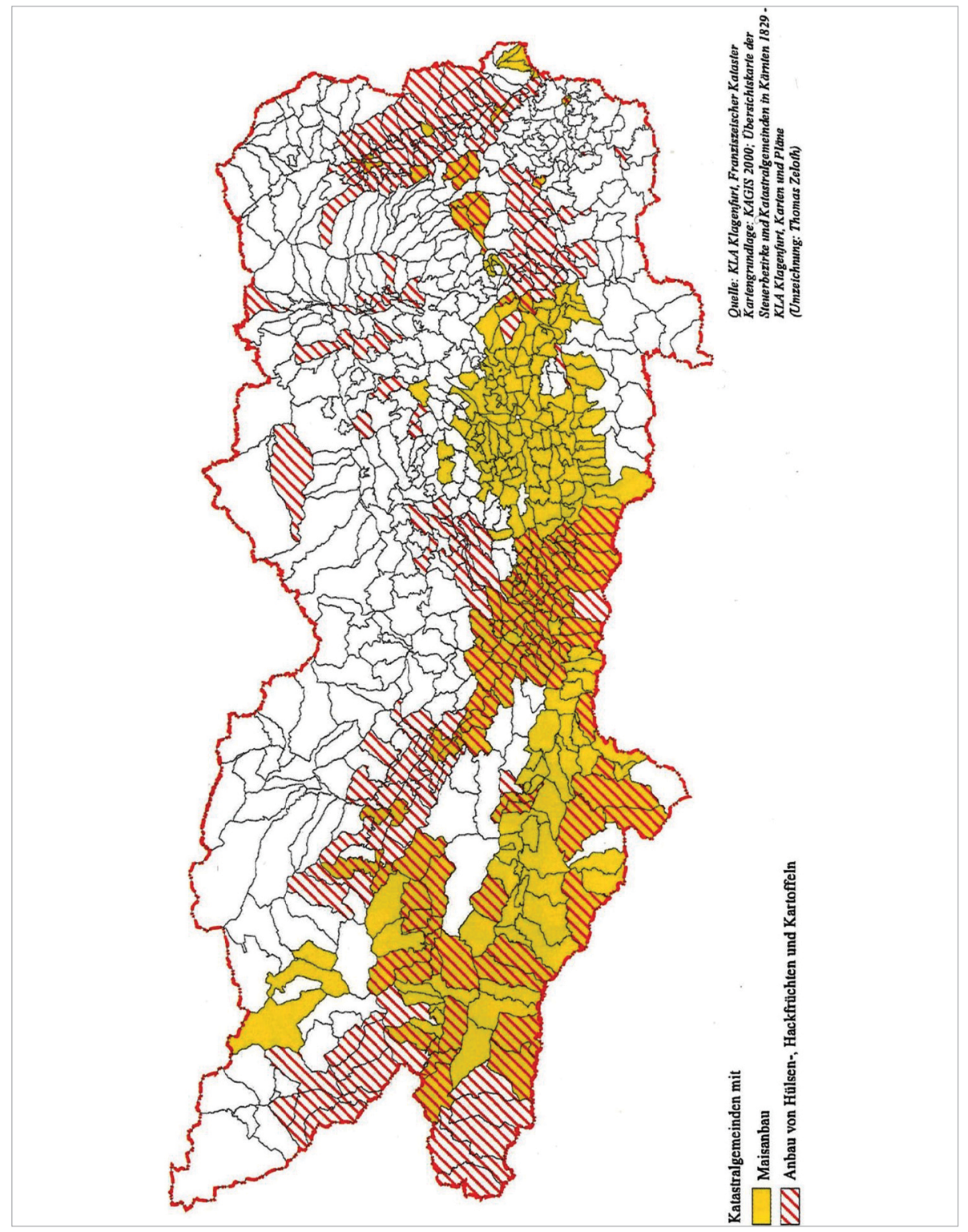

Map I. Maize cultivation by cadastral communities around I830

Legend:

Katastralgemeinde $=$ cadastral community

Maisanbau = maize cultivation

Anbau von Hülsenfrüchten, Hackfrüchten und Kartoffeln = cultivation of legumes, root crops and potatoes 


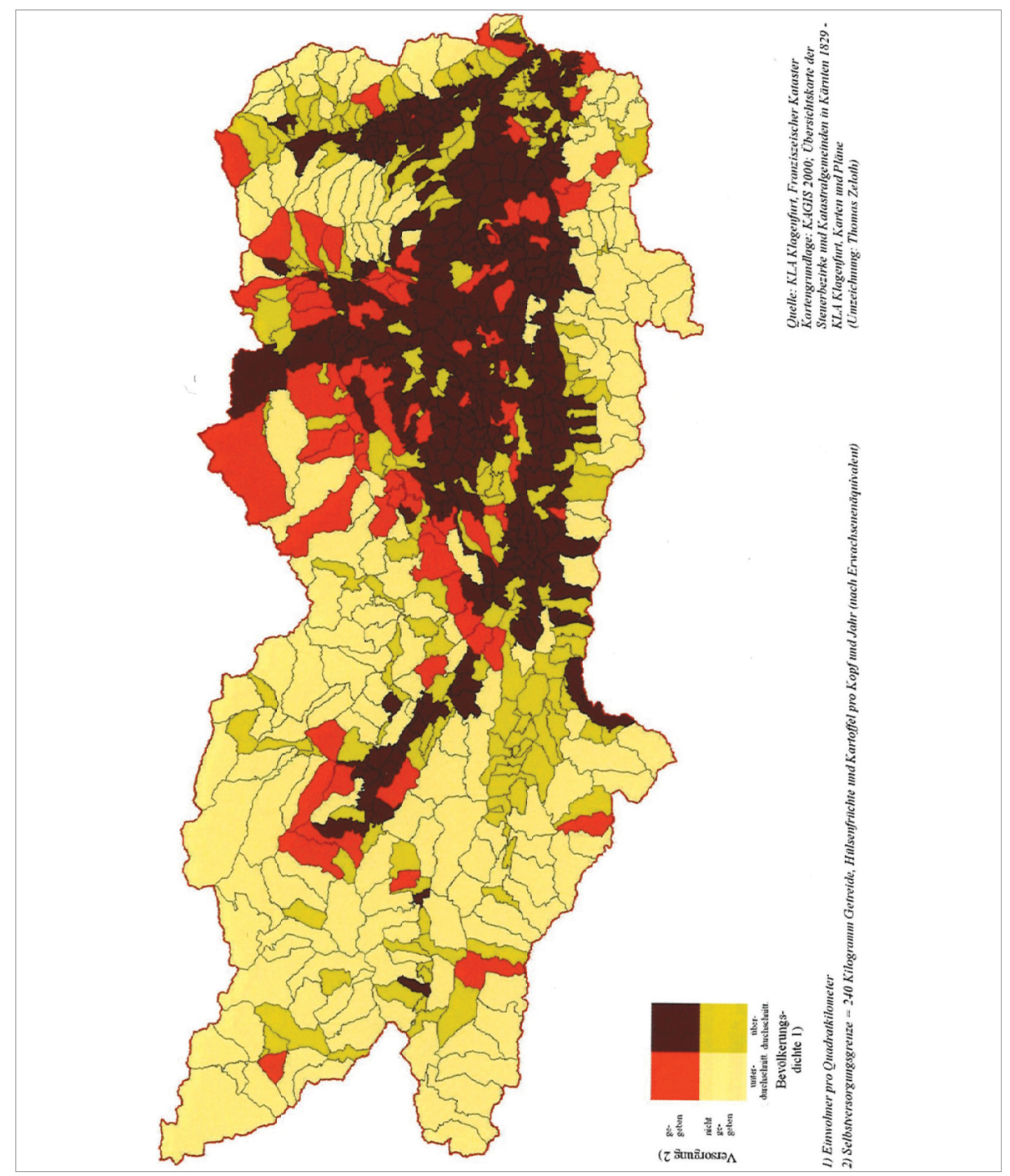

Map 2. Degree of self-sufficiency and population density by cadastral communities around 1830

Legend:

Bevölkerungsdichte $=$ population density ${ }^{1}$; überdurchschnittlich = above average;

unterdurchschnittlich $=$ below average

Versorgung = supply2): gegeben $=$ factual; nicht gegeben = non factual

I) Einwohner pro Quadratkilometer $=$ inhabitants per square kilometer

2) Selbstversorgungsgrenze $=$ self-sufficiency level $-240 \mathrm{~kg}$ grain, legumes and potatoes per capita and year (adult equivalent) 
feathers) were used to fill pillows. An "American Turkish maize ginning machine" was also known (Khackl 1845, 60).

Table r. Cultivation and yields of cereals, legumes and root crops, as well as potatoes, in Carinthia, 1830

\begin{tabular}{lcccc}
\multicolumn{1}{c}{ Crop } & $\begin{array}{c}\text { Yields } \\
\text { in tons }\end{array}$ & $\begin{array}{c}\text { Cultivation } \\
\text { in hectares }\end{array}$ & $\begin{array}{c}\text { Share in the } \\
\text { cultivated area in } \\
\text { percent }\end{array}$ & $\begin{array}{c}\text { Yields in } \\
\text { kilograms per } \\
\text { hectare }\end{array}$ \\
\hline Rye & 35,875 & 45,459 & 35.1 & 788 \\
\hline Oats & $\mathbf{2 2 , 8 7 1}$ & 32,289 & 24.9 & 707 \\
\hline Buckwheat & 7,279 & 18,320 & 14.1 & 397 \\
\hline Wheat & 10,505 & 13,736 & 10.6 & 764 \\
\hline Barley & 7,949 & 9,262 & 7.1 & 773 \\
\hline Maize & $\mathbf{4 , 4 8 5}$ & $\mathbf{2 , 7 4 2}$ & $\mathbf{2 . 1}$ & 831 \\
\hline Millet & 1,891 & 2,275 & 1.8 & 766 \\
\hline Mixed cereals & 1,465 & 1,908 & 1.5 & 919 \\
\hline Foxtail millet & 511 & 556 & 0.4 & 322 \\
\hline Linseed & 123 & 381 & 0.3 & 4.712 \\
\hline Beets & 8,034 & 1,705 & 1.3 & 6.649 \\
\hline Potatoes & 3,391 & 510 & 0.4 & 516 \\
\hline Lentils & 160 & 310 & 0.2 & 1.156 \\
\hline Beans & 133 & 115 & $\mathbf{1 0 . 1}$ & $\mathbf{8 0 8}$ \\
\hline Collectively & $\mathbf{1 0 4 , 6 7 3}$ & $\mathbf{1 2 9 , 5 6 8}$ & & $\mathbf{1 0 0 . 0}$ \\
\hline
\end{tabular}

Source: Zeloth 2013, I48.

The pre-March period was a time of upheaval in the everyday living habits. The results of the cadastral estimates show that the cultivation of maize was increasing throughout the province. In Upper Carinthia, it had penetrated into the mountain valleys. In parts of the Möll Valley and the Lesach Valley it was used as food, although in very small quantities. In 1834, the estimates for the Franciscean Cadastre stated that the main food of the population of the Lesacht Valley was polenta. It was prepared less with maize and more with barley or oats. Maize was cultivated only to a very small extent (Neumann 1997, 205). Not much had changed there, compared to the eighteenth century, because of the lack of population pressure.

The centres of maize cultivation with yields of 100 kilograms and more per capita and per year were the Lower Gail Valley, the area around 
Table 2. Per capita consumption in kilogram per year in Carinthia, I830

\begin{tabular}{lccc} 
& & & \\
& Klagenfurt & District & Carinthia \\
& & Villach & \\
Rye & 124.9 & in kilograms & 100.1 \\
\hline Wheat & 33.8 & 64.3 & 28.1 \\
\hline Oats & 32.7 & 20.0 & 25.5 \\
\hline Buckwheat & 31.9 & 15.0 & 22.0 \\
\hline Maize & $\mathbf{1 4 . 0}$ & 7.7 & $\mathbf{1 7 . 3}$ \\
\hline Barley & 12.6 & $\mathbf{2 2 . 0}$ & 17.2 \\
\hline Millet & 11.9 & 24.0 & 7.2 \\
\hline Mixed cereals & 7.5 & 0.3 & 4.4 \\
\hline Foxtail millet & 2.5 & 0.0 & 1.9 \\
\hline Linseed & 0.0 & 1.1 & 0.5 \\
\hline Potatoes & 4.6 & 1.2 & 5.4 \\
\hline Beets & 5.9 & 6.5 & 10.5 \\
\hline Lentils & 0.7 & 17.1 & 0.4 \\
\hline Beans & 0.8 & 0.0 & 0.5 \\
\hline Collectively & $\mathbf{2 8 3 . 7}$ & 0.0 & $\mathbf{2 4 0 . 9}$ \\
\hline
\end{tabular}

\section{Source: Zeloth 2013, I49.}

Villach, the western Rosental, the area west of Völkermarkt and the central Carinthian area with the Klagenfurt basin. In the cadastral community of Maria Saal, it was the second most cultivated cereal with more than a quarter of the annual gross yield of all cereal cultivation, after rye. In some areas, such as Grafenstein in Central Carinthia or the cadastral community of Treffen, where the annual requirement was calculated at 16.2 hectolitres for ten people, it was used on an equivalent basis to other types of grain, such as buckwheat or millet.

Maize was an important nutritional factor in these areas. However, it was not only used as food for humans. In the area around Klagenfurt and St. Veit an der Glan, the peasants were already using it for fattening pigs. There it had become a true alternative to buckwheat, which it was slowly displacing from the crop rotation system. In some cadastral communities in Kanaltal, such as Flitschl (Fličl, Plezzut,) und Lusnitz (Lužnice, Lusnizza), maize was cultivated almost exclusively. Everywhere it became an integral part of the weekly menu of the rural population. In the cadastral communities of Edling and Spittal an der Drau they had Plenten 


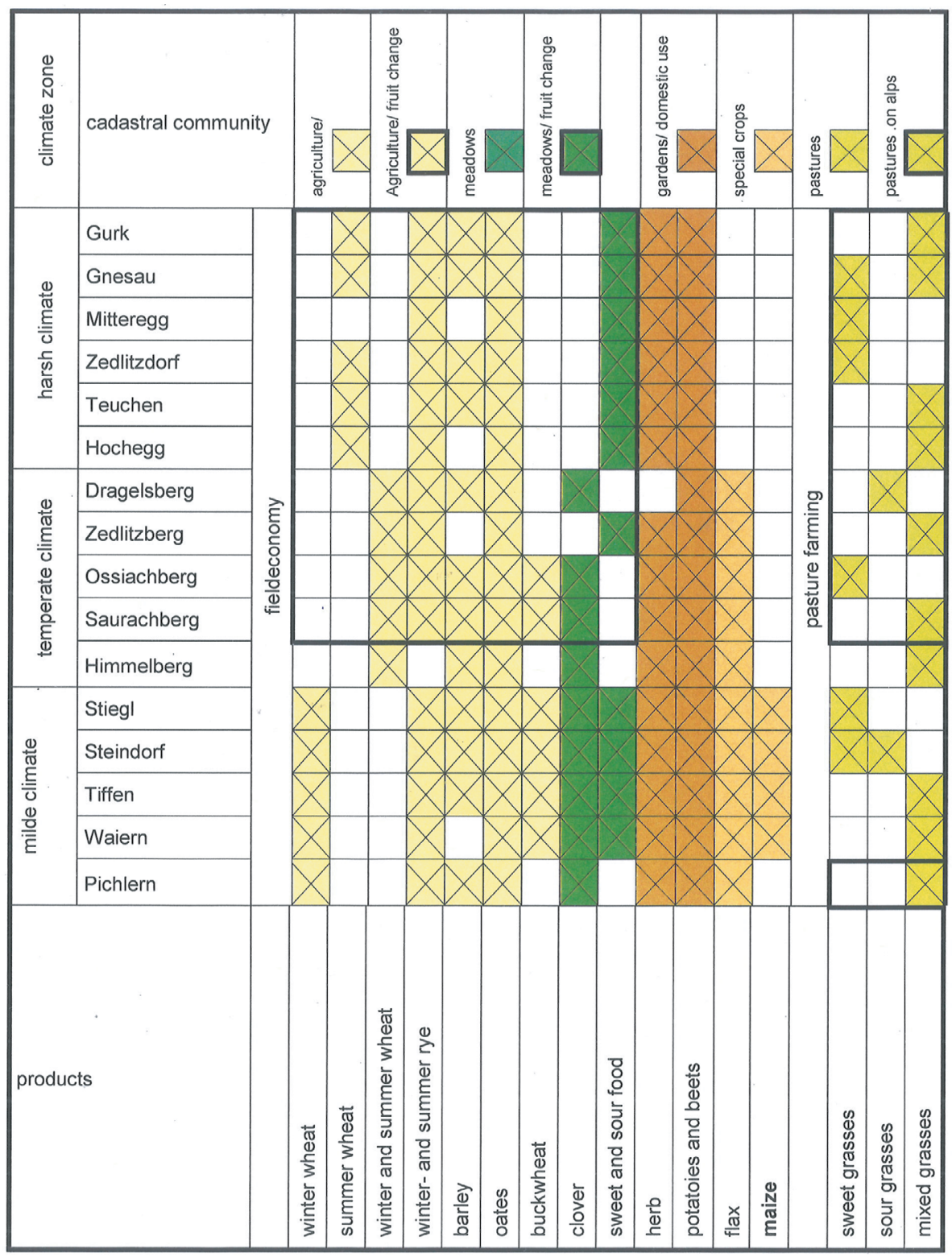

Graph I. Crops by climate zones/cadastral communities in the tax district of Himmelberg, I83I

Source: Johst 2011, 44 . 
Table 3. Harvest results in Carinthia, 1830/ 1871

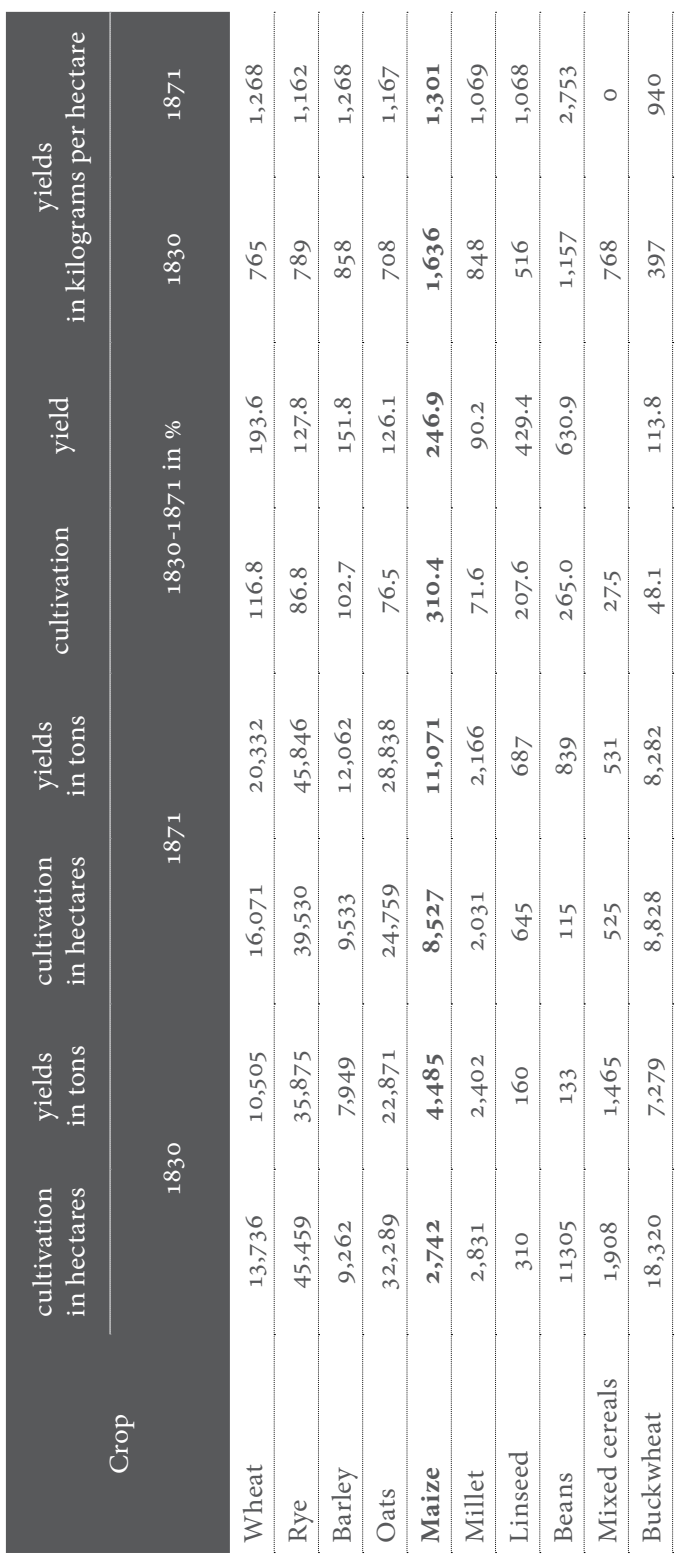

Source: Zeloth 2013, I6I. 
(polenta) for dinner three times a week (Wadl 2013, 166). It was a popular dish and was enjoyed as a daily meal by the many Italians workmen in the country (Hermann 1860, 349). Although the focus of the nutrition around 1830 was still on the traditional porridge dishes made from oats, millet and barley, maize enriched the menu as an innovation. The "modern" or "non-traditional" crops for self-sufficiency - including maize - were cultivated in Upper Carinthia across a larger arable area compared to Lower Carinthia. However, the hectare yields in the Villach district were significantly lower than those of the Klagenfurt district. Maize was harvested in 56 out of 75 tax districts in 1814 (Zeloth 2013, 150). In 1848, the administrator of the manor of Hunnenbrunn (near St. Veit an der Glan), Thomas Khackl, took stock of the development of maize cultivation in Carinthia in an article in the Mittheilungen über Gegenstände der Landwirtschaft und Industrie Kärntens (Khackl 1848, 12-14). According to his explanations, it had been grown in the Gail Valley since the mid-eighteenth century and in Central Carinthia since around 1800 . But the maize, in which Khackl saw an alternative to traditional grain cultivation, was not only consumed in these areas, but also in others. Its yield was above that of traditional cereals. Especially in areas with a mild climate, it joined the "classic" cereals as a new crop, such as in the Himmelberg tax district in Central Carinthia. There it could be found in the inventories of those cadastral communities that were located in a zone with a mild climate.

In the dominion of Hunnenbrunn, also an area with a mild climate, Khackl registered an average of 16.6-33.8 hectolitres per 0.01 hectares between 1816 and 1846 . In places with favourable soil, even 43.1 hectolitres per 0.01 hectares (approximately 6.5 tons per hectare) (Khackl 1848, 14). The peasants also got higher profits from the sale (Wadl 2009, 341).

The triumphal march of maize in Carinthia began at the latest in the 1840 . In the second half of the nineteenth century, the cultivation of a "young" grain such as maize was no longer a question of innovation or persistence, but only of whether it flourished in this or that landscape or not. It is therefore not surprising that cultivation tripled in the second half of the nineteenth century (Table 3 ). The prejudices against maize were finally eliminated. It had established itself as a crop. Wherever the soil and the climate allowed it, the peasants planted it. The rest of its story in Carinthia need not be told here. 


\section{Conclusion: industrialization and population growth} as accelerators of the spread of maize

From the sixteenth century to the first half of the nineteenth century, maize was becoming an increasingly important part of agriculture in Carinthia. But it also became an important food, especially in rural areas. The development of its cultivation varied greatly from region to region and over time. Its more frequent occurrence in the areas which bordered on Italy (Lesach Valley, Gail Valley) suggests that - as Burger suspects - it came to Carinthia from Italy. Gradually, it spread from the mid-eighteenth century onward in the climatically favourable Central Carinthia (Krappfeld, Zollfeld) and during the first half of the nineteenth century towards Lower Carinthia. Its increased spread came at a time when Carinthia's industry, especially the mining industry, experienced a boom. This confirms the thesis that its widespread distribution was the result of early industrialization. This is linked to the beginning of population growth that had far-reaching consequences. The population pressure made it necessary to cultivate maize on a larger scale. With the cultivation of maize, the "inexpensive nutrition of the population became possible [...] which was a prerequisite for the expansion of industrial production" (Sandgruber 1982, 46). After reaching the lowest level in 1812, Carinthia experienced a period of demographic recovery from around 1825 onward. In 1847 , the province had 320,784 inhabitants. Compared to 1816, this growth meant an increase of 20.1 percent, whereby the number of inhabitants in the Klagenfurt district (+24.3 percent) increased more than in the Villach district (+14.4 percent). The population pressure was so great that it made maize cultivation even more necessary, as in the case of potatoes. In this respect, there was an interaction between the spread of maize and the industrialization process in Carinthia, same as elsewhere. Industrialization accelerated its triumphal march.

\section{Bibliography}

Archival sources

AT-KLA, 118-Rosenberg: Kärntner Landesarchiv Klagenfurt, 118-A-11/14 St. (Graf Vinzenz Rosenberg, Inventarium des Erbherzogthum Kärnten über die in selben enthaltenen Physical-, Politisch-, Pecunial- und ComercialGegenstände, verfasset anno 1780). 


\section{Published sources}

Burger, J. 1809. Vollständige Abhandlung über die Naturgeschichte, Cultur und Benützung des Mais oder türkischen Weitzens. Wien: Joseph Geistinger.

Burger, J. 1842. 'Über die Höhe des Bodens über dem Meere, bis zu welchem man in Kärnten und Tirol noch Mais baut.' Carinthia 32: 4-6.

Hain, J. 1853. Handbuch der Statistik des österreichischen Kaiserstaates, vol. II: Wien: Tendler\&Compagnie.

Khackl, Th. 1845: 'Ueber die Anwendbarkeit der amerikanischen TürkenRiefelmaschine'. Mittheilungen über Gegenstände der Landwirtschaft und Industrie Kärntens 8: 60.

Khackl, Th. 1848. 'Maisbau, wie er derzeit in Kärnten betrieben wird.' Mittheilungen über Gegenstände der Landwirtschaft und Industrie Kärntens 5: 12-14.

Mayr, G. 1831. 'Antrittsrede. Gehalten von dem Director der k.k. Gesellschaft zur Beförderung der Landwirthschaft und Industrie in Kärnten Georg Mayr, Fürstbischof zu Gurk, 14. Jänner 1830.' Blätter für Landwirthschaft und Industrie 1: 25-30.

\section{Literature}

Bäck, R. 2005. 'Die „Kärntner Ackerbaugesellschaft“von ihrer Gründung 1764 bis zur Grundentlastung. Eine frühbürgerliche Vereinigung als ökonomisches Modernisierungsinstrument.' Diplomarbeit. Alpen-AdriaUniversity Klagenfurt.

Dinklage, K. 1966. Geschichte der Kärntner Landwirtschaft. Klagenfurt: Heyn.

Dinklage, K. 1970. 'Johann Burger (1773-1842).' In Große Landwirte, edited by G. Franz and H. Haushofer, 103-118. Frankfurt am Main: DLG-Verlag.

Drobesch, W. 2003. Grundherrschaft und Bauer auf dem Weg zur Grundentlastung. Die "Agrarrevolution" in den innerösterreichischen Ländern. Klagenfurt: Verlag des Geschichtsvereins für Kärnten.

Erker, K. 2003. Von Maria Theresia zur EU. Geschichte und Wirken der landwirtschaftlichen Berufskörperschaft Kärntens im Spiegel der eigenen Presse. Klagenfurt: Verlag des Kärntner Landesarchivs.

Hermann, H. 1860. Handbuch der Geschichte des Herzogthumes Kärnten, vol. 3/ 3: Geschichte Kärntens vom Jahre 1780-1857 (1859) oder der neuesten Zeit. Klagenfurt: Verlag Leon.

Johst, W. F. 2011. 'Der Raum des Landgerichtes Himmelberg: Von der wirtschaftlichen Konsolidierung grundherrschaftlichen Besitzes im 18. 
Jahrhundert bis zur Grundentlastung 1848` Dissertation. Alpen-AdriaUniversity Klagenfurt.

Lackner, A. 2014. 'Ökonomie - Gesellschaft - ländliche Lebensweisen im Umbruch. Steuerbezirk und Grundherrschaft Bleiburg 1780-1848.' Dissertation. Alpen-Adria-University Klagenfurt.

Neumann, D. 1997. Das Kärntner Lesachtal. Werden und Wandlungen einer bergbäuerlichen Kultur- und Wirtschaftslandschaft. Klagenfurt: Verlag des Kärntner Landesarchivs.

Roth, F. O. 1970. 'Kärntner Bauern im Urteil der "aufgeklärten Obrigkeit”. Eine volksundlich-kulturgeschichtliche Skizze.' Carinthia II 160: 342-362.

Sandgruber, R.1982. Die Anfänge der Konsumgesellschaft. Konsumgüterverbrauch, Lebensstandard und Alltagskultur in Österreich im 18. und 19. Jahrhundert. Wien: Verlag für Geschichte und Politik.

Tschischej, M. 2013. 'Mais Situation in Kärnten - Rückblick 2013.' (https:// oekl.at/wp-content/uploads/2013/11/Tschischej.pdf; 18.1.2020)

Wadl, W. 1987. 'Alter und Entwicklung der Maiskultur in Kärnten.' Carinthia I 177: 239-251.

Wadl, W. 2009. 'Türkensterz und Erdäpfel. Der Krieg als Motor der Ernährungsinnovation' In Napoleon und seine Zeit. Kärnten Innerösterreich - Illyrien, edited by C. Fräss-Ehrfeld, 335-352. Klagenfurt: Verlag des Geschichtsvereins für Kärnten.

Wadl, W. 2013. 'Ernährung und ländliche Alltagskultur in Kärnten im Spiegel der Katastralschätzungen.' In Kärnten am Übergang von der Agrar-zur Industriegesellschaft. Fallstudien zur Lage und Leistung der Landwirtschaft auf der Datengrundlage des Franziszeischen Katasters (1823-1844), edited by W. Drobesch, 163-170. Klagenfurt: Verlag des Geschichtsvereins für Kärnten.

Zeloth, Th. 2004. Zwischen Staat und Markt. Geschichte der Bleiberger Bergwerks Union und ihrer Vorläuferbetriebe. Klagenfurt: Verlag des Kärntner Landesarchivs.

Zeloth, Th. 2013. 'Die agrarische Selbstversorgung der Bevölkerung Kärntens nach den Daten des Franziszeischen Katasters.' In Kärnten am Übergang von der Agrar-zur Industriegesellschaft. Fallstudien zur Lage und Leistung der Landwirtschaft auf der Datengrundlage des Franziszeischen Katasters (1823-1844), edited by W. Drobesch, 147-162. Klagenfurt. Verlag des Geschichtsvereins für Kärnten.

Zenegg-Scharffenstein, E. 1930. 'Zur Geschichte der Maiskultur in Kärnten.' Carinthia II 119: 54-55. 